\title{
INTERNALISASI NILAI-NILAI TOLERANSI PADA ANAK USIA DINI MELALUI PERMAINAN ANAK DI SEKOLAH (STUDI KASUS DI RAUDHATUL ATHFAL KECAMATAN TEMON)
}

\author{
Asmainah \\ Program Pasca Sarjana \\ Universitas Muhammadiyah Yogyakarta \\ E-mail: asmainah1984@gmail.com
}

\begin{abstract}
Abstrak
Penelitian ini bertujuan untuk mengetahui : (1) gambaran pelaksanaan permainan di RA dalam menginternalisasikan nilai-nilai toleransi. (2)internalisasi nilai-nilai toleransi melalui permainan anak. (3) Permainan yang dapat menginternalisasikan nilai-nilai toleransi pada anak. Metode penelitian yang penulis gunakan adalah penelitian deskriptif kualitatif. Subyek dari penelitian ini adalah kepala sekolah, guru, anak-anak di Raudhatul Athfal I Sindutan dan kepala sekolah, guru, anak-anak, dan orang tua di Raudhatul Athfal Sindutan 2. Adapun temuan-temuan dalam penelitian ini adalah : (1) Permainan anak dilakukan dengan fleksibel dan spontan pada saat anakanak istirahat. (2) Nilai-nilai toleransi dapat tertanam saat anak-anak bersosialisasi dan berinteraksi serta berkomunikasi dengan teman saat mereka bermain. (3) Nilai toleransi banyak ditemukan pada permainan yang melibatkan banyak pemain atau permainan berkelompok dan pada permainan tradisional.
\end{abstract}

Kata kunci: toleransi, anak usia dini, permainan anak

\begin{abstract}
This study aims to determine: (1) a description of the implementation of the game in RA in internalizing tolerance values. (2) internalization of tolerance values through children's play. (3) Games that can internalize tolerance values in children. The research method that I use is descriptive qualitative research. The subjects of this study were the principal, teachers, children in Raudhatul Athfal I Sindutan and the principal, teachers, children, and parents in Raudhatul Athfal Sindutan 2. The findings in this study were: (1) Games children are carried out flexibly and spontaneously when children are at rest. (2) Tolerance values can be embedded when children socialize and interact and communicate with friends when they play. (3) Tolerance values are found in games involving many players or group games and in traditional games.
\end{abstract}

Keywords: tolerance, early childhood, children's play

\section{Info Artikel}

Diterima September 2019, disetujui Oktober 2019, diterbitkan Desember 2019 


\section{PENDAHULUAN}

Menurut Ki Hajar Dewantara, tabiat buruk seseorang baik dengan merusak jiwa atau merusak barang telah dimiliki anak-anak sejak mereka berusia 4 hingga 8 tahun. Anak-anak melakukan vandalisme (merusak barang) yaitu dengan kebiasaan anak-anak mencoret bukunya atau buku anak-anak lain, meludahi teman, meyemprot tinta ke baju anak lain, mencoret-coret meja, melempar barang, tidak mau mengantri saat ingin mencuci tangan, tidak mau menutup kran air dan sebagainya. Sedangkan sikap merusak jiwa adalah dengan mengucilkan teman, merampas barang, dan menyakiti teman.

Indonesia Heritage Foundation telah membuat konsep 9 pilar karakter, setiap pilar adalah kumpulan dari beberapa nilai karakter yang serupa. (1) Cinta Tuhan dengan segenap ciptaan-NYA, (2) Mandiri, Disiplin dan Tanggung Jawab, (3) Jujur, Amanah dan berkata bijak, (4) Hormat dan Santun, (5) Dermawan, Suka menolong dan Kerja sama (6) Percaya diri, Kreatif, dan Pantang Menyerah, (7) Pemimpin yang Baik dan Adil, (8) Baik dan Rendah Hati, (9) Toleransi, Cinta Damai, dan Bersatu.

Menurut Ki Hajar Dewantara, pendidikan karakter kepada pelajar seharusnya diberikan sejak anak-anak mulai memasuki usia dini atau saat mereka memasuki usia prasekolah. Menurunya, pendidikan karakter mampu membentuk mental atau sikap yang baik, salah satu butir nilai perilaku yang baik adalah sikap toleransi terhadap sesamanya. Pengajaran atau penanaman sikap toleransi bagi anak usia dini menurut Ki Hajar Dewantara dapat dilakukan melalui pembiasaan atau percontohan dalam berbagai kegiatan pembelajaran bercerita, menggambar, bermain dengan alat permainan, menyulam, bernyanyi dan kegiatan lainnya.

Menurut Waluya, internalisasi adalah suatu proses yang menjadikan kenyataan sosial yang menjadi kenyataan objektif dan ditanamkan kedalam kesadaran, terutama pada anggota suatu kelompok baru, dalam konteks proses bersosialisasi. Internalisasi nilai merupakan proses panjang memasukkan nilai-nilai secara penuh dan menyeluruh ke dalam hati sehingga ruh dan jiwa bergerak berdasarkan nilai-nilai.

Pendekatan yang sangat tepat untuk mendidik anak adalah dengan bermain, bermain dapat memberikan anak kebebasan dan kesenangan dalam melakukan proses pendidikan. Dan ini sangat sesuai dengan kodrat seorang anak, sebab mendidik anak usia dini bukan dan belum saatnya memberi pengetahuan, akan tetapi baru berusaha akan menyempurnakan akal dan rasa pikiran. Tingkah laku seseorang sangat dipengaruhioleh hati dan pikiran. Maka dari itu perantara untuk menyelaraskan lahir dan batin adalah melalui latihan panca indra. Selanjutnya permainan yang dilakukan dengan panca indra merupakan pekerjaan lahir yang di gunakan untuk mendidik batin.

Santrock berpendapat bahwa permainan merupakan kegiatan yang menyenangkan yang dilakukan untuk kepentingan kegiatan itu sendiri, menurutnya permainan memberi memungkinan kepada anak-anak untuk melepaskan energi fisik mereka yang berlebihan dan membebaskan perasaan yang terpendam. Dengan bermain anak akan menjadi lebih bahagia, sehingga akan mengalami kenyamanan dalam serangkaian kegiatan pembelajaran yang akan diterimanya.

Sepanjang masa usia dini, bermain sangat mempengaruhi penyesuaian pribadi dan sosial anak. Pengaruh bermain bagi perkembangan anak menurut Hurlock:

a. Perkambangan Fisik

b. Dorongan berkomunikasi dan perkembangan sosial

c. Penyaluran bagi energi emosional yang terpendam

d. Sumber belajar dan rancangan kreativitas 
Secara etimologi toleransi berasal dari kata Tolerence (dalam bahasa inggris) yang berarti sikap membiarkan, mengakui dan menghormati keyakinan orang lain tanpa memerlukan persetujuan. Di dalam bahasa arab diterjemahkan dengan tasamuh, berarti saling mengizinkan, saling memudahkan. Toleransi juga dapat dipahami sebagai suatu sikap pengertian dan dapat mengadaptasikan diri sendiri secara positf dan mampu menguntungkan diri sendiri maupun orang lain. Sedangkan dalam kontek sosial toleransi adalah, budaya dan agama yang berarti sikap dan perbuatan yang melarang adanya diskriminasi terhadap suatu golongan.

\section{METODE PENELITIAN}

Penelitian ini menggunakan penelitian kualitatif. Penelitian yang dilakukan bertujuan untuk menggambarkan secara sistematis mengenai fakta-fakta yang ditemukan di lapangan baik bersifat verbal, kalimat, fenomena-fenomena dan bukan merupakan angka. Metode kualitatif berusaha mengungkap berbagai keunikan yang terdapat dalam individu, kelompok, masyarakat atau organisasi dalam kehidupan seharihari secara menyeluruh, rinci, mendalam serta dapat dipertanggung jawabkan secara ilmiah.

Menurut moloeng (1998), sumber data penelitian kualitatif adalah yang berupa kalimat ertulis yang dicermati oleh peneliti, dan benda-benda yang diamati sampai detailnya agar dapat ditangkap makna yang terkandung dalam dokumen atau benda.

Metode penelitian kualitatif digunakan untuk meneliti pada kondisi obyek yang alamiah, dimana peneliti adalah sebagai instrumen kunci, pengambilan sampel sumber data dilakukan secara purposive dan snowbaal, teknik pengumpulan dengan trianggulasi (gabungan), analisis data bersifat induktif/kualitatif lebih menekankan makna daripada generalisasi.

Subjek penelitian sebagaimana dikemukakan Spradley merupakan sumber informasi, sedangkan Moloeng mengemukakan bahwa subjek penelitian merupakan orang dalam pada latar penelitian. Mereka adalah orang yang dimanfaatkan untuk memberikan informasi tentang situasi dan kondisi latar penelitian. Beberapa persyaratan yang harus diperhatikan dalam menentukan subjek penelitian adalah mereka sudah cukup lama dan intesif menyatu dalam kegiatan atau bidang yang menjadi kajian penelitian dan memiliki waktu yang cukup untuk diminta informasi.

Subyek penelitian dan sumber data dalam penelitian ini adalah siswa, para pengasuh atau guru dan kepala sekolah dari Raudhatul Athfal tersebut. Dalam penelitian ini penulis akan memilih beberapa orang yang dipertimbangkan akan memberikan data yang diperlukan, misalnya kepala sekolah sebagai penentu dan pengelola kebijakan, pendidik sebagai sebagai pendamping anak dalam kegiatan dan yang membantu memberikan data, serta wali murid. Semua sumber data tersebut digunakan untuk mengetahui bagaimana menginternalisasikan nilai-nilai toleransi pada anak usia dini melalui permainan anak di Raudhatul Athfal. 


\section{HASIL PENELITIAN DAN PEMBAHASAN}

Diagram 1

Nilai-nilai toleransi yang muncul di Raudhatul Atfal I Sindutan

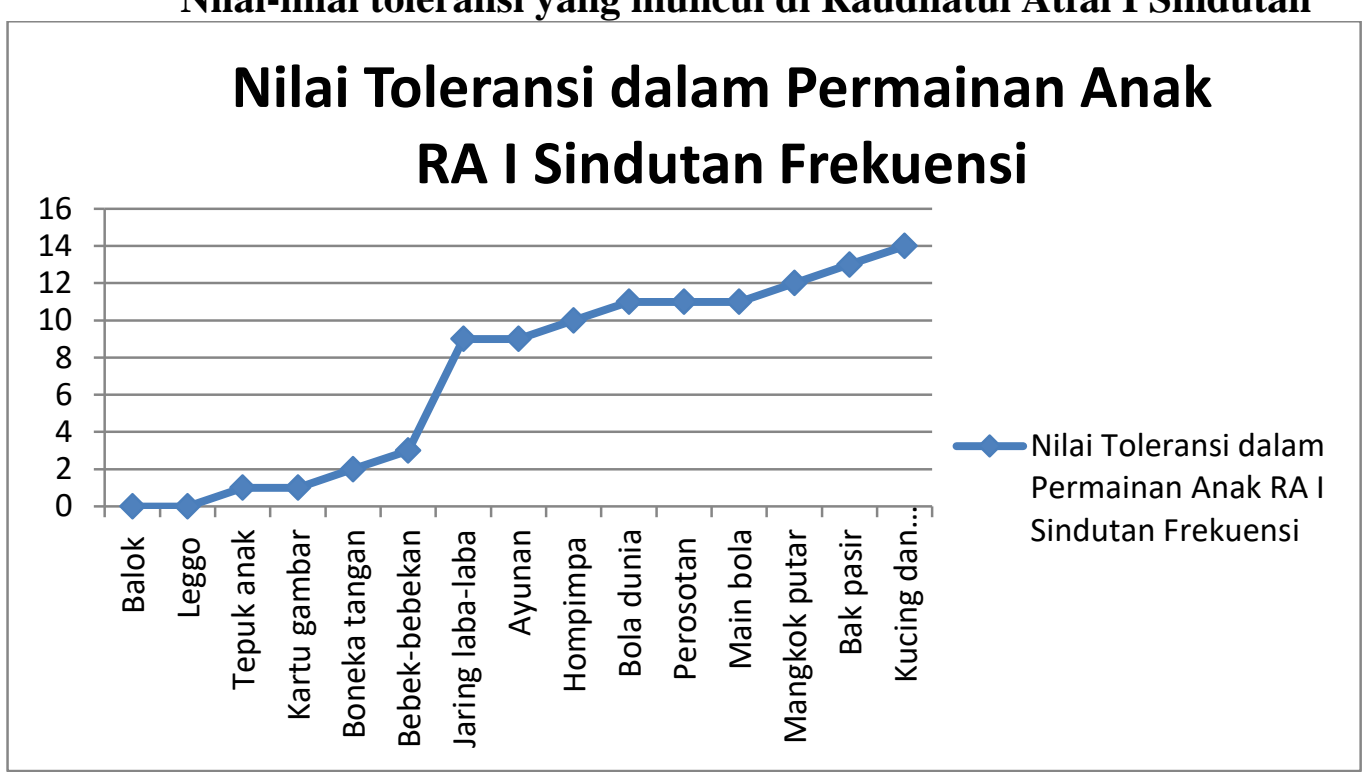

Diagram 2

Nilai-nilai toleransi yang muncul di Raudhatul Atfal Sindutan 2

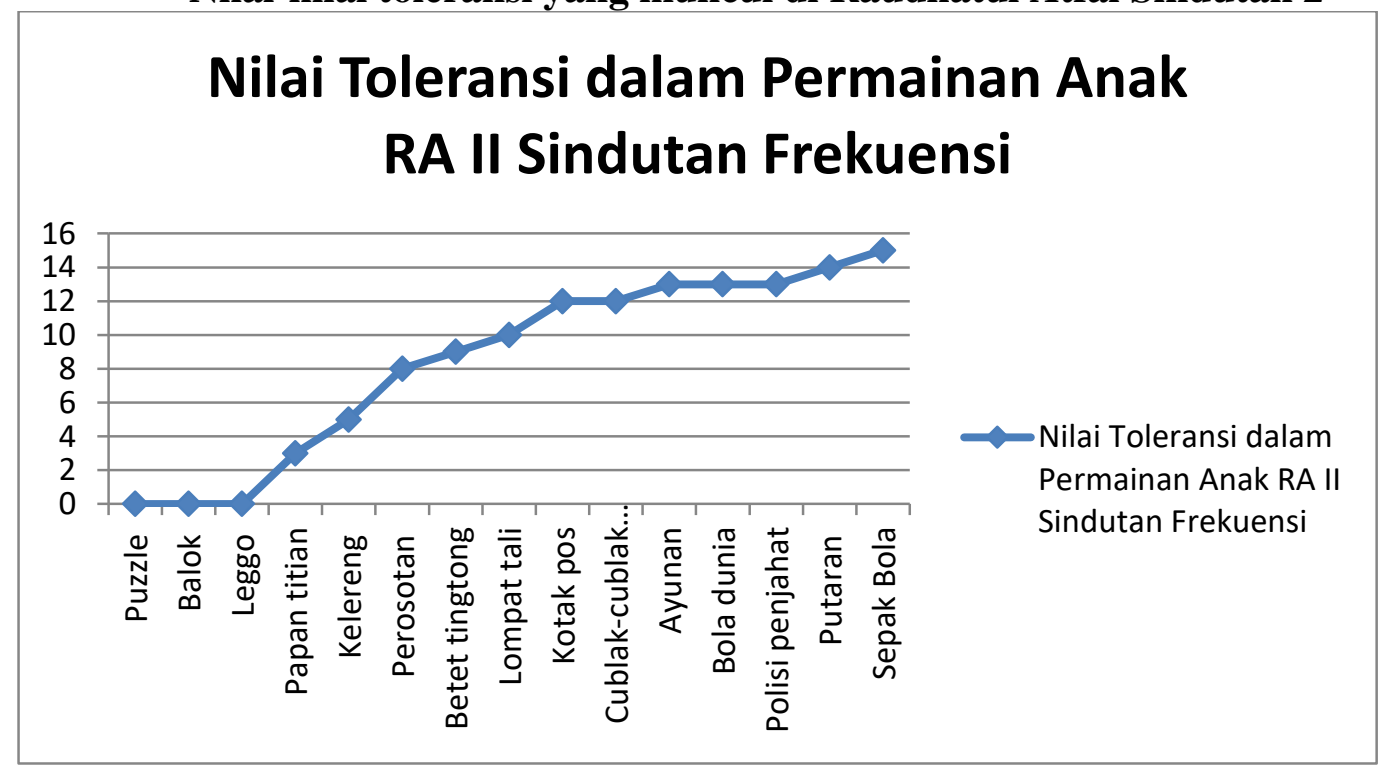

Dari grafik yang telah dipaparkan dapat disimpulkan bahwa jenis permainan anak di Raudhatul Athfal I Sindutan yang mampu memberikan sumbangan terbesar dalam menginternalisasikan nilai-nilai toleransi kepada anak didik adalah permainan tradisional kucing menagkap tikus dan permainan bak pasir. Sedangkan permainan balok, leggo, tepuk anak dan kartu gambar kurang atau tidak memunculkan nilai-nilai toleransi dalam diri anak didik.

Sedangkan permainan anak yang memunculkan nilai-nilai toleransi yang lebih banyak di RA Sindutan 2 adalah permainan sepak bola kemudian permainan putaran, 
ayunan, dan bola dunia, selanjutnya adalah permainan tradisional. Pada permainan sepak bola, nilai kerjasama dan sportifitas sangat terlihat selain kekompakan kebersamaan dan kesabaran. Pada permainan putaran, ayunan dan bola dunia, nilai yang muncul dan paling penting bagi anak-anak adalah mereka mau antri untuk menaiki permainan tersebut secara bergiliran. Dengan mau mengantri anak dapat belajar banyak hal, anak akan bersabar untuk menunggu giliran, anak-anak akan belajar untuk menghormati hak dan milik orang lain dan tidak merebut tempat atau hak oarang lain serta anak belajar untuk mengendalikan sikap egoisnya.

\section{SIMPULAN DAN REKOMENDASI}

a. Permainan di Raudhatul Athfal dilakukan pada saat anak-anak memasuki jam istirahat atau secara fleksibel (setiap hari sabtu untuk permainan bola). Anak-anak RA bermain secara spontan permainan yang mereka inginkan. Anak-anak bermain dengan pengawasan dari guru kelas masing-masing.

b. Permainan sangat mempengaruhi penyesuaian sosial bagi anak. Dalam permainan bebas, anak-anak akan menemukan nilai-nilai toleransi yang sangat bermakna bagi mereka. Tidak jarang dalam bermain anak-anak akan sering menemui perselisihan, pertengkaran dan perbedaan pendapat. Tetapi dengan adanya perselisihan tersebut anak-anak akan belajar menyelesaikan masalahnya dengan mencari jalan keluar bersama-sama dengan cara mereka sendiri. Nilai-nilai toleransi akan muncul dan tertanam dalam diri anak dari permasalahan tersebut, dengan bermain anak-anak akan belajar bersosialisasi, lebih menyayangi teman, menghargai teman, anak belajar untuk tidak membeda-bedakan teman bermain dan yang krusial adalah anak akan peduli dengan teman lainnya. Bermain secara berkelompok akan menuntun anak pada kegiatan sosial dan kebersamaan yang tinggi. Dalam kebersamaan anakanak akan menemukan nilai-nilai positif dan juga mulai berfikir positif, bekerjasama dalam kelompok, belajar saling, menghomati dan menghargai orang lain tanpa anak melihat latar belakang keluarga dan memilih-milih teman. Sedangkan permainan individu atau permainan yang lebih sedikit pemainnya serta lebih banyak alat permainannya akan lebih banyak mengajarkan anak untuk berfikir kreatif dan mengembangkan imajinasinya. Permainan individu menjadikan anak kurang bersosialisasi dikarenakan kurangnya interaksi dengan teman sebayanya.

c. Permainan yang paling banyak memunculkan nilai-nilai toleransi di RA I Sindutan adalah permainan kucing dan tikus yang memunculkan 14 nilai-nilai toleransi, selanjutnya adalah permainan bak pasir memunculkan 13 nilai-nilai toleransi, permainan mangkok putar memunculkan 12 nilai-nilai toleransi, permaian bola, perosotan, bola dunia memunculkan 11 nilai-nilai toleransi, permainan hompimpa, ayunan, dan jaring laba-laba cukup memunculkan nilai-nilai toleransi pada anak. Sedangkan pada permainan tepuk anak, kartu gambar dan boneka tangan kurang memunculkan nilai-nilai toleransi sedangkan dalam permainan leggo dan balok tidak memunculkan nilai-nilai toleransi. Di RA Sindutan 2 permainan yang paling banyak memunculkan nilai-nilai toleransi adalah permainan sepak bola dengan 15 nilai toleransi yang muncul, selanjutnya permainan putaran dengan 14 nilai toleransi, permainan polisi dan penjahat, bola dunia, dan permainan ayunan dengan 13 nilai-nilai toleransi, pada permainan betet ting tong, cublak cublak suweng, lompat tali, kotak pos, kelereng dan perosotan cukup memunculkan nilai-nilai toleransi, sedangkan permainan yang kurang memunculkan nilai-nilai toleransi 
adalah permainan papan titian. Permainan leggo, balok dan puzzle tidak memunculkan nilai-nilai toleransi.

\section{DAFTAR PUSTAKA}

Al-Munawar, Said Agil. 2003. Fikih Hubungan Antar Agama dalam Islam. Jakarta: Penerbit Ciputat Press.

Arikunto,Suharsimi. 2013. Prosedur Penelitian. Jakarta: Rineka Cipta.

Dewantara, Ki Hajar. 1997. Pendidikan. Yogyakarta: Majelis Luhur Persatuan Taman Siswa.

Digdoyo, Eko. 2015. Ilmu Sosial dan Budaya Dasar. Jakarta: Ghalia Indonesia.

Faziah \& Lalu Muchsin Effendi. 2015. Psikologi Dakwah. Jakarta: Prenadamedia Group.

Hasyim, Umar. 1979. Toleransi dan Kemerdekaan Beragama dalam Islam. Surabaya: PT Bina Ilmu.

Hurlock, Elizabet B. 1994. Perkembangan Anak. Jakarta: Erlangga.

Kilmiyah, Akhif. 2016. Metode Penelitian Kualitatif. Yogyakarta: Samudra Biru.

Megawangi, Ratna. 2015. Pendidikan Karakter. Depok: Indonesia Heritage Foundation.

Waluya, Bagja. 2007.Memyelami Fenomena Sosial Di Masyarakat. Bandung: PT Setya Purnama Inves.

Nugroho, Bimo. 2014. Indonesia Memilih Jokowi. Jakarta: Gramedia Pustaka Utama.

Setiawan, Cahya Budi. 2013.Kamus Karakter Bangsa. Bandung: CV Titian Ilmu.

Seefeldt, Carol \& Barbara A. Wasik. 2008. Pendidikan Anak Usia Dini. Jakarta: PT INDEKS.

Muhtar, Tatang. 2018. Internalisasi NIlai Kesalehan Sosial. Sumedang: UPI Sumedang Press

Najati, Muhammad Utsman. 2000. Psikologi Qurani. Bandung: Penerbit Marja.

Rahmad, Fauzi. 2011. Islamic Parenting. Yogyakarta: Penerbit Erlangga.

Roopnaire, Jaipul L. \& James E. Johnson. 2011. Pendidikan Anak Usia Dini Dalam Berbagai Pendekatan. Jakarta: Jakarta Kencana. 
Salam, Syamsir. 2010. Menuju Islam Berperadaban. Jakarta: UIN Jakarta Press.

Samani, Muhlasin dan Hariyanto. 2011. Konsep dan Model Pendidikan Karakter. Bandung: PT Remaja Rosda Karya.

Santrock, Jhon W. 2002. Life-Span Developmen: Perkembangan Masa Hidup. Jakarta: Erlangga

Sugiyono. 2016. Metode Penelitian Pendidikan. Bandung: Alfabeta.

Sujiono, Yuliani Nurani. 2009. Konsep Dasar Pendidikan Anak Usia Dini. Jakarta: PT INDEKS. 